\title{
An Archaeological Survey for the Cibolo Creek Municipal Authority, South Central Texas
}

\section{J. A. Jaquier}

Follow this and additional works at: https://scholarworks.sfasu.edu/ita

Part of the American Material Culture Commons, Archaeological Anthropology Commons, Environmental Studies Commons, Other American Studies Commons, Other Arts and Humanities Commons, Other History of Art, Architecture, and Archaeology Commons, and the United States History Commons

Tell us how this article helped you.

This Article is brought to you for free and open access by the Center for Regional Heritage Research at SFA ScholarWorks. It has been accepted for inclusion in Index of Texas Archaeology: Open Access Gray Literature from the Lone Star State by an authorized editor of SFA ScholarWorks. For more information, please contact cdsscholarworks@sfasu.edu. 
An Archaeological Survey for the Cibolo Creek Municipal Authority, South Central Texas

Creative Commons License

(c) (i) (8)

This work is licensed under a Creative Commons Attribution-NonCommercial 4.0 International License 


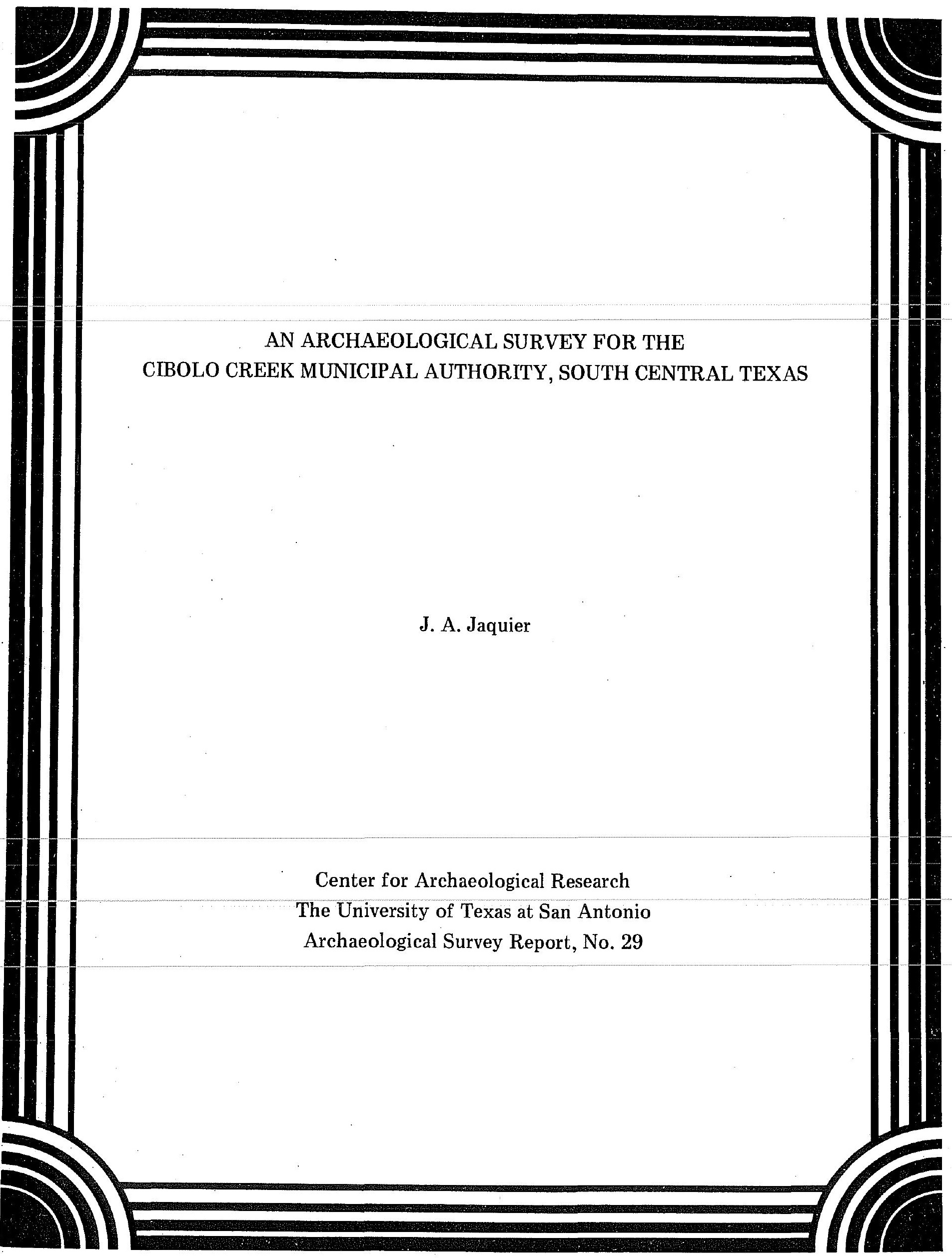


CIBOLO CREEK MUNICIPAL AUTHORITY, SOUTH CENTRAL TEXAS

J. A. Jaquier

Center for Archaeological Research The University of Texas at San Antonio Archaeological Survey Report, No. 29 


\section{TABLE OF CONTENTS}

$\begin{array}{lc} & \text { Page } \\ \text { Preface } & \text { i } \\ \text { Introduction } & 1 \\ \text { Archaeologica]-Backgroüd } & 1 \\ \text { Survey Procedures } & 2 \\ \text { Survey Results } & 2 \\ \text { Concluding Comments } & 7 \\ \text { References Cited } & 7\end{array}$

\section{LIST OF FIGURES}

Figure

Page

1. Location of Survey Area Number One

3

2. Location of Survey Area Number Two

5 3. Location of Survey Areas Number Three
and Four 


\section{PREFACE}

In November, 1976, an archaeological survey was carried out in portions of the Cibolo Creek watershed in Bexar, Comal and Guadalupe Counties in south-central Texas. These investigations resulted from an agreement between the Cibolo Creek Municipal Authority and the Center for Archaeological Research of The University of Texas at San Antonio. The archaeological assessment was necessitated by the proposed installation of gravity-fed sewage lines along tributaries of Cibolo Creek in the area surrounding the city of Selma, Texas. This report presents the results of the archaeological survey.

Thomas R. Hester

Director,

Center for Archaeological Research 
During November, 1976, personnel of the Center for Archaeological Research, The University of Texas at San Antonio, carried out archaeological surveys in the watershed of Cibolo Creek in the Texas counties of Bexar, Comal and Guadalupe. Fieldwork was conducted by J. A. Jaquier and Fred Valdez, Jr. under the supervision of Mr. Jack Eaton, Research Associate of the Center. Four areas (Figs. 1-3) surrounding the city of Selma, Texas, had been proposed for installation of gravity-fed sewage lines by the Cibolo Creek Municipal Authority. In order to assess the prehistoric and historic resources within the four survey areas, the survey team carried out field studies following these-five guidelines:

1. To determine if archaeological resources exist within each of the four areas proposed for sewage line installation.

2. If resources were found, the significance of each was to be recorded, identified, and appraised.

3. To evaluate the impact of project installation on each resource.

4. To provide recommendations for mitigation of the anticipated adverse impacts of such installation.

5. To provide estimates of costs required for mitigation (salvage, protection, etc.).

Standard archaeological survey procedures were utilized during the course of the assessment. Intensive foot surveys were carried out in those localities where construction had been proposed. Terrain features on the margins of the construction area were also investigated. In addition to fulfiling those obligations outlined above, the survey team was instructed to record a variety of other data so that the resulting information could be used in future archaeological studies in the region.

\section{ARCHAEOLOGICAL BACKGROUND}

Although extensive scientific archaeology has been conducted in Bexar County, comparatively little has taken place in Comal and Guadalupe Counties. Extensive research under an archaeological salvage program in the Canyon Reservoit area of Coma 7 County was carried out in 1959-1960 by The University of Texas at Austin (Johnson, Suhm and Tunne11 1962) with more recent studies by the Center for Archaeological Research (Hester, Bass, and Kelly 1975; Kelly and Hester 1975a, 1975b). And, a recent summary of Guadalupe County archaeology appears in Hester (1975). A summary of earlier work in Bexar County has been published by Fawcett (1972). along with a bibliography of published and unpublished reports dealing with Bexar County archaeological research. Among the types of sites found in the three counties are open occupation sites (campsites), burned rock middens, chert quarries and workshops (see Kelly and Hester 1975b), temporary campsites (probably a result of seasonal hunting and gathering activities), rockshelters, and burial caves (Collins 1970). Based on the Canyon Reservoir research, Johnson, Suhm, and Tunne11 (1962: Fig. 45) proposed the following divisions in the region's prehistory: Paleo-Indian (roughly 9200-6000 B.C.); Archaic (6000 B.C. to A.D. 1000); Neo-American (or Late 
Prehistoric, approximately A.D. 1000 to 1600). Each of these major time periods is characterized by specific kinds of artifacts; changes in temporal span are recognized by alterations in projectile point style. Prehistoric archaeological sites in the region are frequently situated along stream courses and on low stream terraces. Indian populations frequented the three county region, camping on the banks of Cibolo Creek, and one campsite dubbed "Turkey Hil1," has been discovered in the immediate area and recorded at the Texas Archeological Research Laboratory (site number 47 BX 35).

\section{SURVEY PROCEDURES}

The survey team is indebted to Mr. C. Johnson, Environmentai Services Coordinator of the Cibolo Creek Municipal Authority for securing maps of the area and for obtaining property owner permission. When the actual field survey work began, $\mathrm{Mr}$. Johnson and a secretary, Miss Deborah Ponder, personally accompanied the survey crew to each survey area, assisting the crew in physically locating the survey line and guiding the crew over the course of the survey in the face of very inclement weather. For their outstanding assistance and cooperation, the Center for Archaeological Research is deeply grateful.

The survey was accomplished by a two-person survey team which walked the entire course of each area where the installation of sewage lines had been proposed. The crew covered each bank of the creeks or low areas to a distance of at least 50 feet from the centerline of the plotted surveys. Through the courtesy of Mr. 0. J. Riedel, President of the Board of Directors of the Cibolo Creek Municipal Authority, an aerial survey of the four areas was also planned; however, the inclement weather prevented this aspect of the study. The survey team nevertheless wishes to thank Mr. Lew Borgfeld of Maupin and Borgfeld Aviation for his efforts on our behalf.

All artifacts, field notes, maps and other materials resulting from survey activities are on file at the Center for Archaeological Research, The University of Texas at San Antonio. Persons interested in the specific climate, geology, soils, vegetation, and faunal patterns in the four survey areas near cibolo Creek are referred to the Cibolo Creek Recreational Site Analys is published by the Division of Environmental Studies of The University of Texas at San Antonio on August 5, 1976.

Area 1: This survey area extends in a north-northwesterly direction from Maske Road in the south to IH 35 in the north (Fig. 1). The southernmost point of the survey line begins at a fence 7 ine on Maske Road, 3575 feet northeast of FM 1518. The survey line runs north-northeastward just inside the western edge of the Schertz Corporate Boundary for 1500 feet, at which point it assumes a slightly more northerly direction running in a straight line for 4900 feet to a point just west of an unidentified road in an area slated for subdivision construction. The unidentified road 7 ies approximately 4500 feet to the east of FM 1518. The survey line then proceeds north-northwestward in a straight line and intersects with IH 35 at a culvert. A short alternate route beginning at the northern end of this unidentified road and heading in a northnortheasterly direction along the 750 foot contour line to the southwest corner of a trajler park was also surveyed. The trailer park is located approximately 500 feet to the southwest of the intersection of IH 35 and 


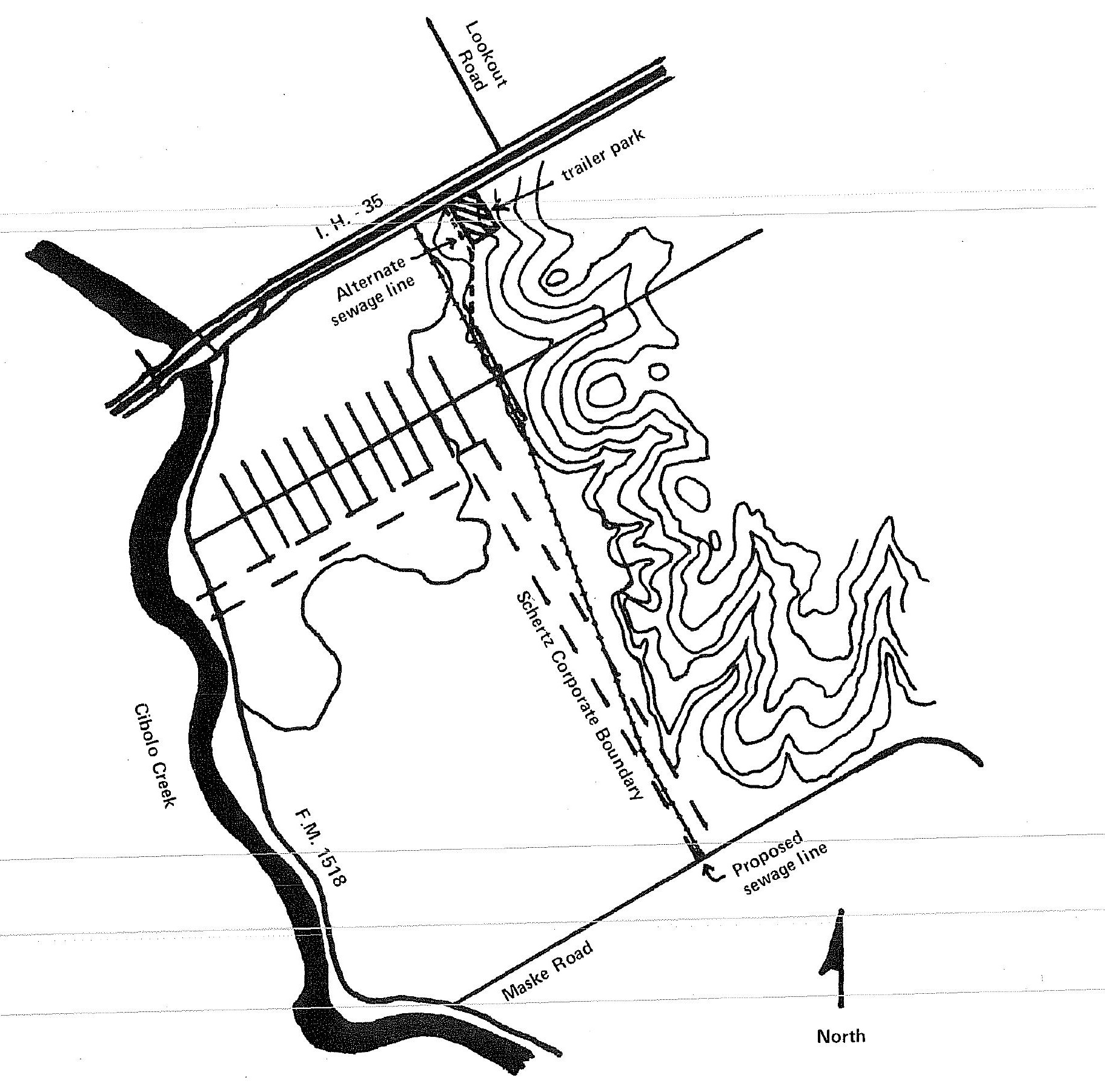

Figure 1. Location of Survey Area Number One: A sewage line proposed by the Cibolo Creek Municipal Authority in Guadalupe County, Texas. 
Lookout Road. The proposed sewage line lies entirely within the 750 foot contour line. Generally speaking, the southern portion of the survey area runs through plowed fields, while the central portion is mostly brush and live oak. Although some cedar elm and oak were noted by the margins of the unnamed creek along which the survey line is plotted. The northern portion of this line runs through tall grass until it nears IH 35, where it once again runs through a plowed field. The soil appears to be a grayish brown silty clay loam with slow to medium surface drainage (Lewisville-Houston Black terrace association). The nearly level alluvial soil should have high natural fertility and the extensively plowed areas indicate desireable farm land. No crops were growing at the time of the survey al though there was evidence of a recent harvest of sorghum. It was only in the central wooded area that the creek actually cuts below the surface soils, at times to a depth of three or four feet. Neither historic nor prehistoric sites were noted along this survey line although the distal end of one heavily patinated projectile point was found in the creek gravel in the central area. This projectile point obviously represented a secondary deposition since a thorough search of the surrounding area revealed no further lithics. The survey area is characterized by the extremely level terrace and a poorly defined stream channel some four to five thousand feet east of cibolo creek. Evidence of flooding may be seen almost 100 feet distance from either side of the channel.

Area 2: This survey area (Fig. 2) is situated in an area bounded generally on the east by an unnamed road west of FM 3009, on the west by Lookout Road, on the north by the Missouri-Kansas-Texas Railroad and on the south by IH 35 . The survey line is located just to the south and along a fenceline which runs in a general east/west direction. The area has been disturbed by plowing although no crops were growing during the survey. The soil is a rich, dark alluvium with virtually no rock. Vegetation has been cleared to permit the plowing of the fields. No trace of aboriginal utilization of this area was discernible.

Area 3: This survey line (Fig. 3) runs south-southeasterly from Lookout Road for approximately 1500 feet to a point just north-northwest of the easternmost road in a planned housing development. It is generally bounded on the east by FM 1518, on the south by IH 35, and on the west by Grote Cemetery. The survey area was plowed at the time of the inspection, although no crops were planted. A fenceline forms the eastern edge of the survey area. The soil is once again a dark alluvium and the larger vegetation has been completely cleared. Nothing of an archaeological significance was observed in this area.

Area 4: This survey area (Fig. 3) extends from Lookout Road in a westerly direction, crossing Converse Road (FM 1604) and terminating at Nacogdoches Road (FM 2252) halfway between Topperwein and Converse Roads. From a point just west of the intersection of Lookout and Grote Cemetery Roads, the survey line generally parallels a small unnamed creek north of the line. The area is marked by low, grassy terraces studded with live oak which give way to plowed fields to the west. Just east of the Missouri-Kansas-Texas raiTroad tracks, the survey line runs through low-lying pasture in heavy grass. To the south of the creek in this area, there is a moderately high (15 feet) 


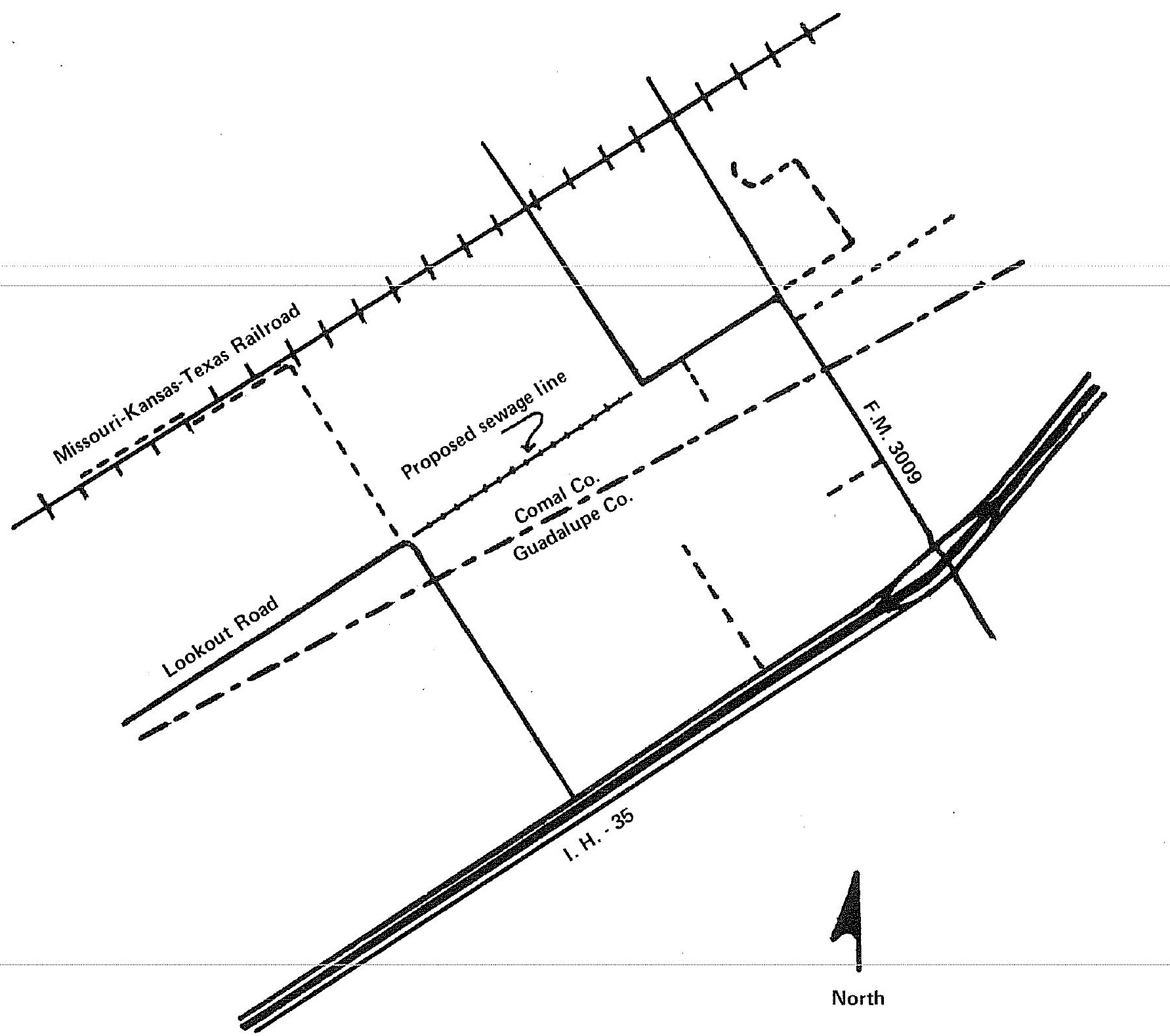

Figure 2. Location of Survey Area Number Two: A sewage line proposed by the Cibolo Creek Municipal Authority in Comal County, Texas. 
This page has been

redacted because it

contains restricted

information. 
hill upon which is a windmi17. To the west of this windmi11 is a smal1 quarry site (41 BX 401) with large nodules of chert protruding above the surface at the edge of the plowed terrace. Many of these nodules show the effect of percussion flaking designed to remove the cortex. Survey team members observed and recorded the surface lithic scatter and collected six of the smaller representative cores (on file, Center for Archaeological Research). Large decortication flakes could be seen on the surface and some of the chert showed light patination.

The survey line then crosses the railroad tracks and, proceeding south of a large man-made tank, extends to the northeast to Nacogdoches Road. This latter area is characterized by cleared pasture land for its entire length west of FM 1604.

\section{CONCLUDING COMMENTS}

A single archaeological site (41 BX 401) was found during the survey. No further investigations appear to be warranted at that locality. Aside from this site nothing of an archaeological significance was noted in any of the four survey areas. It is recognized that minor deviations from the planned construction line may occur during pipeline installation. For this reason, the Center for Archaeological Research requests that the construction crews be briefed to alert the Cibolo Creek Municipal Authority upon discovery of anything which might constitute an archaeological site. When contacted by the C.C.M.A., the Center for Archaeological Research will promptly investigate any such discoveries.

\section{REFERENCES CITED}

Collins, M. B.

1970 On the Peopling of Hitzfelder Cave. Bulletin of the Texas Archeological Society $41: 301-304$.

Fawcett, W. B., Jr.

1972 The Prehistory of Bexar County: A Study of Previous Work in South Central Texas. Bulletin of the Lower Plains Archeological society 2:23-44.

Hester, T. R. (assembler)

1975 Archaeological and Historical Resources in the San AntonioGuadalupe River Basins: A Preliminary Statement. Center for Archaeological Research. The University of Texas at San Antonio, Regional Studies 1.

Hester, T. R., F. A. Bass, Jr., and T. C. Kelly

1975 Archaeological Survey of Portions of the Comal River Watershed, Comal County, Texas. Center for Archaeological Research, The University of Texas at San Antonio, Archaeological Survey Report 6. 
Kelly; T. C. and T. R. Hester

1975a Additional Archaeological Survey in the Dry Comal Watershed, Comal County, South Central Texas. Center for Archaeological Research. The University of Texas at San Antonio, Archaeological Survey Report 10.

1975b Archaeological Investigations at Four Sites in the Dry Comal Watershed, Comal County, South Central Texas. Center for Archaeological Research. The University of Texas at San Antonio, Archaeological Survey Report 15.

Johnson, L., Jr., D. A. Suhm, and C. D. Tunne11

1962 Salvage Archeology of Canyon Reservoir: The Wunderlich, Footbridge, and Oblate Sites. Texas Memorial Museum Bulltin 5. 